\title{
Pengaruh Penerapan Alat Peraga Puzzle dengan Menggunakan Metode Demonstrasi Terhadap Motivasi Belajar Siswa Pada Pembelajaran Matematika di SD/MI
}

\author{
Ahmad Arifuddin ${ }^{11}$, Syibli Maufur², Farida $^{3}$ \\ ${ }^{123}$ Jurusan Pendidikan Guru Madrasah Ibtidaiyah, IAIN Syekh Nurjati Cirebon
}

\author{
A R T I C L E I N F O \\ Article history: \\ Received 22 November \\ 2017 \\ Received in revised form \\ 18 Desember 2017 \\ Accepted 13 Januari 2018 \\ Available online 20 \\ Februari 2017 \\ Kata Kunci: \\ Alat Peraga Puzzle, \\ Demonstrasi, Motivasi \\ Belajar \\ Keywords: \\ Puzzle Props, \\ Demonstration, Learning
}

\begin{abstract}
A B S T R A K
Penelitian ini bertujuan untuk mengetahui seberapa besar pengaruh penerapan alat peraga puzzle dengan menggunakan metode demonstrasi terhadap motivasi belajar siswa pada pembelajaran matematika di SD / MI. Penelitian ini merupakan penelitian kuantitatif, menggunakan desain One Shot Case Study. Teknik pengumpulan data yang digunakan adalah kuesioner dan observasi. Subyek dalam penelitian ini adalah seluruh siswa kelas IV-1 MI An-Nur Kota Cirebon yang berjumlah 38 siswa. Teknik analisis data yang digunakan dalam penelitian ini adalah uji angket, uji determinasi dan Coefisient Regression Test. Berdasarkan hasil uji regresi, ditemukan bahwa nilai signifikansi sebesar 0,000 . Sehingga nilai signifikansi lebih kecil dari 0,05 dan thitung sebesar 6,608 lebih besar dari t tabel 2,03011, maka Ho ditolak. Ini berarti bahwa penerapan alat peraga puzzle dengan menggunakan metode demonstrasi pada pembelajaran matematika memiliki pengaruh yang signifikan terhadap motivasi belajar siswa di kelas IV MI An-Nur Kota Cirebon.
\end{abstract}

\section{A B S T R A C T}

This study aims to determine how much influence the application of puzzle props by using demonstration methods to student's learning motivation on learning mathematics in SD / MI. This research is a quantitative research, using One Shot Case Study design. Data collection techniques used were questionnaires and observations. Subjects in this study were all students of grade IV-1 MI An-Nur Cirebon City which amounted to 38 students. The technique of data analysis used in this research is questionnaires test, determination test and Coefisient Regression Test. Based on regression test results, it is found that the significance value of 0.000 . So that the significance value is smaller than 0.05 and $t$ arithmetic of 6,608 is greater than $t$ table of 2.03011, then Ho is rejected. This means that the application of puzzle props by using demonstration method on learning mathematics have a significant influence to student's learning motivation in class IV MI An-Nur Cirebon City.

\footnotetext{
${ }^{1}$ Corresponding author,

E-mail addresses: arief.udien4@gmail.com (Ahmad Arifuddin)
} 


\section{Pendahuluan}

Matematika merupakan salah satu mata pelajaran yang wajib diberikan kepada semua peserta didik mulai dari jenjang sekolah dasar hingga jenjang menengah. Hal ini dimaksudkan untuk membekali peserta didik dengan kemampuan berpikir logis, analisis, sistematis, kritis serta kemampuan bekerja sama (BSNP, 2006). Kemampuan-kemampuan tersebut diperlukan agar peserta didik dapat memperoleh, mengelola, dan memanfaatkan informasi untuk bertahan hidup pada keadaan yang selalu berubah, tidak pasti, dan kompetitif sesuai dengan tuntutan perkembangan zaman (Sartika, Kaswari, \& Suryani, 2013).

Menurut penelitian yang dilakukan oleh (Fuadiah, Zulkardi, \& Saleh, 2009) dan (Rahmadonna \& Fitriyani, 2011) mengungkapkan bahwa salah satu masalah mendasar dalam pembelajaran matematika adalah masih rendahnya motivasi dan prestasi dalam belajar matematika. Rendahnya motivasi dan prestasi dalam belajar matematika ini menurut (Sundayana, 2016) salah satunya disebabkan kurangnya siswa dalam memahami materi pelajaran matematika. Selain itu, matematika merupakan pelajaran yang sukar dipahami. Dampaknya, motivasi untuk belajar matematika menurun, sehingga berpengaruh terhadap prestasi belajar siswa pada pembelajaran matematika.

Salah satu inovasi dalam pembelajaran yang dapat membantu siswa dalam memahami materi pelajaran matematika adalah dengan menggunakan media pembelajaran. Hal ini sesuai dengan pendapat Ibrahim dalam (Arsyad, 2011) yang menyatakan bahwa penggunaan media pembelajaran dalam proses belajar mengajar dapat membangkitkan kegiatan dan minat yang baru, membangkitkan motivasi dan rangsangan kegiatan belajar, bahkan membawa pengaruh psikologis terhadap siswa. Menurut Purwanita, 2013 motivasi dapat diartikan sebagai suatu dorongan yang menuntun seseorang untuk mencapai apa yang diinginkan. Motivasi adalah suatu proses untuk menggalakkan suatu tingkah laku supaya dapat mencapai maklumat-maklumat yang tertentu. Selain itu, penggunaan media pembelajaran juga dapat membantu siswa meningkatkan pemahaman, menyajikan data dengan menarik dan terpercaya, memudahkan penafsiran, serta memadatkan informasi. Oleh karena itu, idealnya dikembangkan media pembelajaran untuk setiap mata pelajaran yang dilengkapi dengan fasilitas dan sumber belajar sebagai perangkat pembelajaran. Menurut Santika (2017) motivasi berasal dari kata motiv yang artinya sebagai daya upaya dalam diri yang mendorong sesorang untuk melakukan sesuatu. Motivasi dapat diartikan sebagai daya penggerak dari dalam dan dari dalam subjek untuk melakukan aktivitas tertentu demi menjacapai suatu tujuan. Menurut Nandang (2017) motivasi merupakan faktor yang sangat penting dalam proses belajar guna mencapai prestasi yang diharapkan. Motivasi merupakan pendorong dan penggerak individu yang dapat menimbulkan dan memberikan arah bagi individu untuk melakukan aktivitasaktivitas tertentu untuk mencapai tujuannya. Motivasi adalah keseluruhan daya penggerak di dalam diri siswa yang menimbulkan kegiatan belajar yang menjamin kelangsungan dari kegiatan belajar dan memberikan arah sehingga tujuan yang dikehendaki dapat tercapai (Ermelinda, 2017).

Di antara bentuk media pembelajaran adalah alat peraga pembelajaran. Alat peraga adalah suatu hal yang dapat diserap oleh mata dan telinga dengan tujuan membantu guru agar proses belajar mengajar siswa lebih efektif dan efisien (Sudjana, 2014). Untuk itu, seorang guru harus mampu memilih dan menentukan berbagai aspek yang dapat menunjang proses pembelajaran agar berjalan dengan baik dan efektif, salah satunya adalah pemilihan alat peraga dan metode pembelajaran yang tepat agar siswa mudah menerima pembelajaran dan tidak pasif saat kegiatan belajar mengajar. Ketepatan pemilihan alat peraga dan metode pembelajaran tentu didasarkan pada karakteristik materi yang akan disampaikan, keadaan kelas, jumlah siswanya, maupun fasilitas yang ada di sekolah tersebut.

Berdasarkan hasil observasi yang peneliti lakukan di beberapa Madrasah Ibtidaiyah (MI) di Kota Cirebon, salah satunya di MI An-Nur Kota Cirebon ditemukan permasalahan bahwa siswa kurang termotivasi dalam belajar matematika. Kurangnya motivasi dalam belajar matematika tersebut karena siswa mengalami kesulitan dalam mempelajari matematika. Hal ini disebabkan karena guru hanya menggunakan metode ceramah dan penugasan bahkan sering kali tidak menggunakan media atau alat peraga, sehingga siswa merasa jenuh dan bosan dalam mengikuti pelajaran matematika.

Hal ini juga diperkuat dengan hasil wawancara dengan salah satu guru mata pelajaran matematika kelas IV pada tanggal 19 Mei 2017 yang mengatakan bahwa guru memang jarang menggunakan alat peraga dan metode yang tepat dalam proses pembelajaran. Hal itu terjadi karena beberapa faktor, salah satunya yaitu kurangnya kesiapan guru, baik itu dari segi waktu, biaya, tenaga, sarana dan prasarana yang kurang mendukung, sehingga guru kurang efektif dalam menerapkan alat peraga atau metode tertentu dalam proses belajar mengajar.

Sehubungan dengan permasalahan tersebut, maka peneliti mencoba menerapkan alat peraga puzzle dengan menggunakan metode demonstrasi untuk meningkatkan motivasi belajar siswa pada mata pelajaran matematika, khususnya pada materi pokok bangun datar. Menurut penelitian yang dilakukan oleh (Lestari, Raga, \& Sudatha, 2014) mengemukakan bahwa media/Alat Peraga Puzzle merupakan alat 
peraga yang sangat menarik dan bisa mendukung dalam proses pembelajaran karena media puzzle dapat meningkatkan minat siswa dalam belajar matematika. Berbagai macam bentuk, ukuran, gambar, dan potongan-potongan pada media puzzle sangat menarik bagi siswa untuk menyusun, merangkai dan mencocokan bentuk potongan puzzle pada tempatnya dan sangat cocok untuk diterapkan pada materi bangun datar. Penelitian yang senada juga telah dilakukan oleh (Astuti, Parmiti, \& Wirya, 2014) yang menyatakan bahwa Puzzle bisa memberikan kesempatan belajar yang banyak kepada anak. Kemampuan kognitif serta rasa percaya diri siswa pun akan muncul sehingga siswa akan termotivasi dan merasa yakin mampu menyusun media puzzle. Menurut Tantri (2013) puzzle dapat membuat siswa menjadi lebih semangat dalam mengikuti pembelajaran karena Puzzle termasuk alat permainan edukatif (APE). APE dirancang untuk mengembangkan kemampuan anak belajar sejumlah keterampilan sehingga dapat meningkatkan hasil belajar siswa.. Hidayat (2017) media puzzle sebagai alat bantu untuk mengoptimalkan proses pembelajaran dengan cara bermain dan berdiskusi. Dalam penelitian yang dilakukan oleh (Elan, Muiz, \& Feranis, 2017) juga menyatakan bahwa Puzzle mampu meningkatkan kemampuan siswa dalam mengenal bentuk geometri.

Sementara itu, metode demonstrasi menurut (Sanjaya, 2009) adalah metode pembelajaran dengan memperagakan dan mempertunjukkan kepada siswa tentang suatu proses, situasi, atau benda tertentu. Menurut Darmawan (2017) penggunaan metode demonstrasi dinilai akan dapat menghidupkan suasana kelas dibandingkan bila siswa membaca atau hanya mendengarkan. Menurut Andriani (2013) Metode demonstrasi memiliki ciri-ciri yang nantinya memberikan kesempatan kepada anak untuk memperkirakan apa yang akan terjadi. Menurut Nonik (2013) Tujuan metode demonstrasi yaitu memberi pengalaman belajar melalui melihat dan mendengarkan yang diikuti dengan meniru pekerjaan yang didemonstrasikan, kegiatan yang sesuai dengan metode ini yaitu kegiatan demonstrasi yang dimulai dengan penjelasan, kemudian kegiatan demonstrasi dalam bentuk dramatisasi. Melalui peragaan yang dilakukan juga akan memberikan gambaran konkrit serta memperjelas pencermatan siswa pada materi yang dipelajari. Dengan menggunakan metode demonstrasi tersebut menurut penelitian yang telah dilakukan oleh (Akhdinirwanto, 2011) proses penerimaan siswa terhadap materi pelajaran berkesan lebih mendalam sehingga membentuk pengertian dengan baik dan sempurna. Senada dengan hal tersebut, (Sudjana, 2014) juga menyatakan bahwa metode demonstrasi merupakan metode mengajar yang efektif, sebab dapat membantu siswa untuk mencari jawaban dengan usaha sendiri berdasarkan fakta (data) yang benar. Menurut Kembar (2013) metode demonstrasi adalah suatu cara untuk mempertunjukkan/ memperagakan suatu objek/proses dari suatu kejadian atau peristiwa. Metode demonstrasi adalah cara penyajian bahan pelajaran dengan memperagakan atau mempertunjukkan kepada siswa mengenai suatu proses, situasi, atau benda tertentu yang sedang dipelajari baik sebenarnya maupun tiruan disertai penjelasan lisan

Penelitian ini bertujuan untuk mendeskripsikan respon siswa terhadap penerapan alat peraga puzzle dengan menggunakan metode demonstrasi pada pembelajaran matematika materi bangun datar di kelas IV MI An-Nur Kota Cirebon; 2) mengetahui motivasi belajar siswa pada pembelajaran matematika materi bangun datar di kelas IV MI An-Nur Kota Cirebon; 3) mengetahui seberapa besar pengaruh penerapan alat peraga puzzle dengan menggunakan metode demonstrasi terhadap motivasi belajar siswa pada pembelajaran matematika materi bangun datar di kelas IV MI An-Nur Kota Cirebon.

\section{Metode}

Penelitian ini merupakan penelitian kuantitatif dengan menggunakan pre-eksperimental design. Bentuk pre-eksperimental design dalam penelitian ini adalah One-Shot Case Study. Pada desain One-Shot Case Study ini terdapat suatu kelompok yang diberi treatmen/ perlakuan, dan selanjutnya diobservasi hasilnya (Sugiyono, 2015). Treatmen/perlakuan yang dimaksud adalah penerapan alat peraga puzzle dengan menggunakan metode demonstrasi.

Penelitian ini dilaksanakan di MI An-Nur Kota Cirebon pada bulan April hingga Juni 2017. Populasi dalam penelitian adalah seluruh siswa MI An-Nur Kota Cirebon. Sementara itu, sampel yang digunakan adalah seluruh siwa kelas IV-1 MI An-Nur Kota Cirebon yang berjumlah 38 siswa. Pengambilan sampel dalam penelitian ini menggunakan teknik purposive sampling, yaitu suatu cara pengambilan sampel berdasarkan pada pertimbangan atau tujuan tertentu, serta berdasarkan pada ciri-ciri atau sifat-sifat tertentu yang sudah diketahui sebelumnya (Sugiyono, 2015). Adapun yang menjadi pertimbangan peneliti mengambil sampel kelas V-I diantaranya adalah siswa kurang termotivasi untuk belajar pada pembelajaran matematika, siswa merasa jenuh ketika belajar matematika, serta dalam proses pembelajaran matematika siswa jarang menerima penerapan alat peraga/media dan metode yang efektif.

Sementara itu, teknik pengumpulan data yang digunakan pada penelitian ini adalah menggunakan teknik observasi, angket, dan dokumentasi. Teknik observasi digunakan untuk memperoleh data tentang 
respon siswa terhadap penerapan alat peraga puzzle dengan menggunakan metode demonstrasi pada pembelajaran matematika materi bangun datar. Selanjutnya, angket digunakan untuk memperoleh data tentang motivasi siswa dalam mengikuti pembelajaran matematika menggunakan alat peraga puzzle dan metode demonstrasi. Sedangkan teknik dokumentasi digunakan untuk memperoleh data yang mendukung proses penelitian. Adapun instrumen penelitiannya yaitu lembar observasi dan lembar angket. Dalam penelitian ini, peneliti menggunakan lembar observasi dan angket yang digunakan untuk mendapatkan data variable X dan Y yaitu pengaruh penerapan alat peraga puzzle dengan menggunakan metode demonstrasi terhadap motivasi belajar siswa.

Sedangkan teknik analisis data yang digunakan dalam penelitian ini adalah rumus prosentase skor angket dan uji regresi sederhana. Rumus prosentase skor angket ini menurut (Arikunto, 2011) menggunakan kriteria sangat lemah (skor 0\%-20\%), lemah (21\%-40\%), cukup (41\%-60\%), kuat (61\%$80 \%$ ), dan sangat kuat (81\%-100\%). Adapun uji regresi sederhana dilakukan untuk mengetahui seberapa besar pengaruh antara satu variabel independen dengan satu variabel dependen atau satu variabel bebas terhadap satu variabel terikat yang ditampilkan dalam bentuk persamaan regresi. Variabel independen (bebas) dilambangkan dengan X, sedangkan variabel dependen (terikat) dilambangkan dengan Y. Setelah pengolahan data selesai, data pada bagian tabel coefficients dimasukan ke dalam rumus. Rumus yang digunakan untuk menguji persamaan regresi sederhana adalah $Y=a+B x$ (Sugiyono, 2015).

\section{Hasil dan Pembahasan}

Respon siswa terhadap penerapan alat peraga puzzle dengan menggunakan metode demonstrasi pada pembelajaran matematika materi bangun datar di kelas IV MI An-Nur Kota Cirebon.

Hasil respon siswa terhadap penerapan alat peraga puzzle dengan menggunakan metode demonstrasi pada pembelajaran matematika materi bangun datar dapat dilihat pada tabel 1 berikut:

Tabel 1. Data Respon Siswa

\begin{tabular}{lllllllllll}
\hline & $\mathbf{1}$ & & $\mathbf{2}$ & & $\mathbf{3}$ & & $\mathbf{4}$ & \multicolumn{3}{l}{ Jumlah } \\
\cline { 2 - 11 } & F & S & F & S & F & S & F & S & F & S \\
\hline Jumlah & 1 & 1 & 19 & 38 & 165 & 495 & 195 & 780 & 380 & $\mathbf{1 3 1 4}$ \\
\hline
\end{tabular}

Berdasarkan tabel 1 di atas diperoleh informasi bahwa dari 38 responden dengan jumlah item angket sebanyak 10, diperoleh skor total sebesar 1314. Sementara itu, skor ideal untuk data respon siswa tersebut adalah 10 item x 38 responden $\times 4$ (skor tertinggi tiap item) $=1520$. Maka presentase pencapaian skor respon siswa adalah:

$$
\frac{1314}{x+100 \Omega 4}=86 \%
$$

Skor tersebut tergolong pada kategori sangat kuat yaitu berada di antara 81\% - 100 .

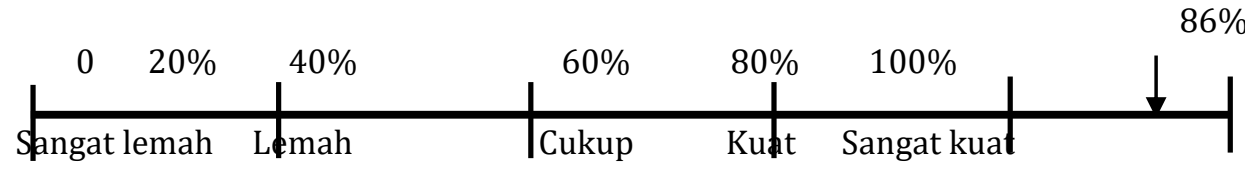

Berdasarkan hasil penelitian yang telah disajikan di atas menunjukkan bahwa dari 38 responden dengan jumlah item angket sebanyak 10 untuk respon siswa terhadap penerapan alat peraga puzzle dengan menggunakan metode demonstrasi pada pembelajaran matematika diperoleh skor total hasil penyebaran angket respon siswa sebesar 1314. Sementara itu, skor ideal untuk variabel tersebut adalah sebesar 1520. Sehingga diperoleh presentase pencapaian skor respon siswa adalah sebesar $86 \%$. Skor tersebut tergolong pada kategori sangat kuat yaitu berada di antara $81 \%$ - 100. Jadi dapat disimpulkan bahwa respon siswa terhadap penerapan alat peraga puzzle dengan menggunakan metode demonstrasi pada pembelajaran matematika sangat kuat, yakni sebesar $86 \%$.

Motivasi belajar siswa setelah penerapan alat peraga puzzle dengan metode demonstrasi pada pembelajaran matematika materi bangun datar di kelas IV MI An-Nur Kota Cirebon.

Data motivasi belajar siswa setelah penerapan alat peraga puzzle dengan menggunakan metode demonstrasi pada mata pelajaran matematika materi bangun datar dapat dilihat pada tabel 2 berikut: 
Tabel 2. Data Motivasi Belajar

\begin{tabular}{lllllllllll}
\hline & 1 & & 2 & & 3 & \multicolumn{3}{l}{4} & \multicolumn{3}{l}{ Jumlah } \\
\cline { 2 - 11 } & F & S & F & S & F & S & F & S & f & S \\
\hline umlah & 3 & 3 & 40 & 80 & 175 & 525 & 162 & 648 & 380 & $\mathbf{1 2 5 6}$ \\
\hline
\end{tabular}

Tabel 2 di atas menunjukkan bahwa skor total hasil penyebaran angket motivasi belajar siswa adalah sebesar 1256. Sementara itu, skor ideal untuk variabel motivasi belajar tersebut adalah 10 item x 38 responden $\mathrm{x} 4$ (skor tertinggi tiap item) $=1520$. Sehingga presentase pencapaian skor motivasi belajar siswa adalah:

$$
\frac{1256}{1520} \times 100 \%=83 \%
$$

Skor tersebut tergolong pada kategori sangat kuat yang beradadi antara $81 \%-100 \%$.

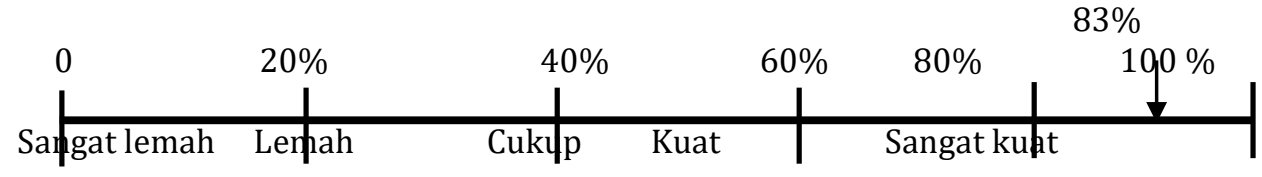

Berdasarkan hasil penelitian yang telah disajikan di atas menunjukkan bahwa dari 38 responden dengan jumlah item angket sebanyak 10 untuk motivasi belajar siswa pada saat penerapan alat peraga puzzle dengan menggunakan metode demonstrasi pada pembelajaran matematika diperoleh skor total hasil penyebaran angket motivasi belajar siswa sebesar 1256. Sementara itu, skor ideal untuk variabel tersebut adalah sebesar 1520. Sehingga diperoleh presentase pencapaian skor respon siswa adalah sebesar 83\%. Skor tersebut tergolong pada kategori sangat kuat yaitu berada di antara 81\% - 100. Jadi dapat disimpulkan bahwa motivasi belajar siswa pada saat penerapan alat peraga puzzle dengan menggunakan metode demonstrasi pada pembelajaran matematika sangat kuat, yakni sebesar 83\%.

Pengaruh penerapan alat peraga puzzle dengan menggunakan metode demonstrasi pada pembelajaran matematika materi bangun datar terhadap motivasi belajar siswa di kelas IV MI AnNur Kota Cirebon

a. Uji Determinasi (R Square)

Tabel 3. Uji Determinasi

\begin{tabular}{llllc}
\hline Model & $\mathrm{R}$ & R Square & Adjusted R Square & Std. Error of the Estimate \\
\hline 1 & $.740^{\mathrm{a}}$ & .548 & .536 & 1.78523 \\
\hline
\end{tabular}

a. Predictors: (Constant), penggunaan alat peraga puzzle

b. Dependent Variable: motivasi belajar

Pada Tabel 3 di atas diketahui bahwa R Square sebesar 0,548 (kuadrat dari koefisien korelasi 0,740). R Square disebut koefisien determinan yang dalam hal ini 54,8\%. Dari nilai tersebut dapat diartikan bahwa penerapan alat peraga puzzle menggunakan metode demonstrasi pada pembelajaran matematika materi bangun datar berpengaruh sebesar 54,8\% terhadap motivasi belajar matematika materi bangun datar pada siswa kelas IV MI An-Nur Kota Cirebon, sedangkan sisanya dipengaruhi oleh faktor lain.

b. Uji Koefisien Regresi

\begin{tabular}{|c|c|c|c|c|c|c|}
\hline \multirow[t]{2}{*}{ Model } & & \multicolumn{2}{|c|}{$\begin{array}{l}\text { Unstandardized } \\
\text { Coefficients }\end{array}$} & $\begin{array}{l}\text { Standardized } \\
\text { Coefficients }\end{array}$ & \multirow[t]{2}{*}{$\mathrm{T}$} & \multirow[t]{2}{*}{ Sig. } \\
\hline & & $\mathrm{B}$ & Std. Error & Beta & & \\
\hline & (Constant) & 3.861 & 4.427 & & .872 & .389 \\
\hline 1 & $\begin{array}{ll}\text { Alat } & \text { Peraga } \\
\text { Puzzle } & \\
\end{array}$ & .844 & .128 & .740 & 6.608 & .000 \\
\hline
\end{tabular}

Tabel 4. Uji Koefisien Regresi 


\section{$Y=a+b X$}

Y adalah variabel dependent, dalam hal ini adalah Motivasi belajar matematika materi bangun datar, dan $\mathrm{X}$ adalah variabel independent, dalam hal ini adalah penerapan alat peraga puzzle dengan menggunakan metode demonstrasi. Sedangkan a dan $\mathrm{b}$ adalah nilai konstanta yang dicari.

Berdasarkan hasil regresi pada tabel 4 diketahui nilai constant-nya adalah sebesar 3.861 dan nilai alat peraga puzzle adalah sebesar 0.844. Dari keterangan tersebut kita dapat memperoleh persamaan regresi berikut ini: sebagai berikut:

\section{$\boldsymbol{Y}=3.861+0.844 \boldsymbol{X}$}

Nilai konstanta dari koefficien regresi sebesar 3.861, hal ini menyatakan bahwa jika tidak ada kenaikan nilai atau skor dari variabel penerapan alat peraga puzzle dengan menggunakan metode demonstrasi, maka variabel penerapan alat peraga puzzle dengan menggunakan metode demonstrasi adalah sebesar 3.861. Koefficien regresi sebesar 0.844 menyatakan bahwa setiap terjadi penambahan skor variabel penerapan alat peraga puzzle dengan menggunakan metode demonstrasi akan dapat menambah kenaikan variabel motivasi belajar.

Setelah mengetahui besarnya koefisien regresi, maka perlu dilakukan pengujian hipotesis untuk megetahui apakah terdapat pengaruh atau tidak. Uji hipotesis dapat dinyatakan dengan membandingkan nilai signifikan yaitu :

Jika nilai signifikan $>0,05$ dan $\mathrm{t}_{\text {hitung }}<\mathrm{t}_{\text {tabel, }}$, maka $\mathrm{H}_{0}$ diterima

Jika nilai tidak signifikan $<0,05$ dan $\mathrm{t}_{\text {hitung }}<\mathrm{t}_{\text {tabel, }}$, maka $\mathrm{H}_{0}$ ditolak

Jika tabel dicari dengan $\alpha=0,05$ dan (df) n-k-1 atau 38-2-1 $=35$, jadi tabel $=2.03011$

Hasil uji koefisien regresi pada tabel 4 di atas menunjukkan bahwa nilai signifikansinya sebesar 0,000. Karena nilai signifikansinya lebih kecil dari 0,05 dan $t$ hitung (6.608) lebih besar dari $t$ tabel (2.03452) maka Ho ditolak, artinya bahwa penerapan alat peraga puzzle dengan menggunakan metode demonstrasi berpengaruh signifikan terhadap motivasi belajar matematika materi bangun datar pada siswa kelas IV MI An-Nur Kota Cirebon. Jadi dapat disimpulkan bahwa penerapan alat peraga puzzle menggunakan metode demonstrasi berpengaruh signifikan terhadap motivasi belajar matematika materi bangun datar pada siswa kelas IV MI An-Nur Kota Cirebon sebesar 54,8\%, sedangkan sisanya dipengaruhi oleh faktor lain.

Berdasarkan uraian hasil penelitian di atas menunjukkan bahwa respon dan motivasi belajar siswa terhadap penerapan alat peraga puzzle dengan menggunakan metode demonstrasi pada pembelajaran matematika sangat kuat, yakni sebesar $86 \%$ dan $83 \%$. Kuatnya respon dan motivasi belajar siswa terhadap penerapan alat peraga puzzle dengan menggunakan metode demonstrasi pada pembelajaran matematika tersebut menurut penelitian yang dilakukan oleh (Srianis, Suarni, \& Ujianti, 2014), dan (Lestari, Raga, \& Sudatha, 2014) karena alat peraga puzzle itu sendiri merupakan alat peraga yang sangat menarik dan bisa mendukung dalam proses pembelajaran, sehingga dapat meningkatkan minat siswa dalam belajar matematika. Hasil penelitian yang dilakukan oleh (Sugiarta, Gitakarma, \& Nugraha, 2015) juga memperkuat hasil penelitian ini yang mengemukakan bahwa alat peraga puzzle yang didemonstrasikan di depan siswa membuat perhatian siswa menjadi lebih terfokus sehingga proses pembelajaran lebih aktif dan menarik. Selain itu, penggunaan metode demonstrasi menurut (Sanjaya, 2009) juga membuat proses pembelajaran lebih menarik, sebab siswa tidak hanya mendengar, tetapi juga melihat peristiwa yang terjadi. Hasil penelitian yang dilakukan oleh (Arjanggi, Tandililing, \& Ramdani, 2013) juga mengungkapkan bahwa penerapan metode demonstrasi dapat meningkatkan motivasi belajar siswa dalam pembelajaran matematika.

Sementara itu, penerapan alat peraga puzzle dengan menggunakan metode demonstrasi berpengaruh signifikan terhadap motivasi belajar siswa pada pembelajaran matematika materi bangun datar. Hal ini karena penerapan alat peraga puzzle dengan menggunakan metode demonstrasi dapat menumbuhkan minat belajar siswa sehingga proses pembelajaran menjadi lebih menarik, memperjelas makna bahan pelajaran sehingga siswa lebih mudah memahaminya, metode pembelajaran lebih bervariasi sehingga siswa tidak akan mudah bosan, serta membuat siswa lebih aktif melakukan kegiatan pembelajaran, seperti mengamati, melakukan dan mendemonstrasikan alat peraga puzzle (Sudjana, 2014). Hasil penelitian ini juga diperkuat dengan hasil penelitian yang dilakukan oleh (Arifuddin \& Arrosyid, 2017) dan (Arjanggi, Tandililing, \& Ramdani, 2013) yang mengungkapkan bahwa metode demonstrasi berpengaruh signifikan terhadap motivasi dan hasil belajar matematika.

\section{Simpulan dan Saran}

Berdasarkan hasil penelitian dan pembahasan dapat disimpulkan bahwa respon siswa terhadap penerapan alat peraga puzzle dengan menggunakan metode demonstrasi pada mata pelajaran matematika 
materi bangun datar di kelas IV MI An-Nur Kota Cirebon tergolong pada kategori sangat kuat yaitu 86\% karena berada diantara $81 \%-100 \%$. Sementara itu, motivasi belajar siswa pada pembelajaran matematika materi bangun datar di kelas IV MI An-Nur Kota Cirebon memiliki peningkatan yang signifikan setelah adanya penerapan alat peraga puzzle dengan menggunakan metode demonstrasi dalam proses pembelajaran. Motivasi belajar siswa tersebut tergolong pada kategori sangat kuat yaitu 83\% karena berada diantara $81 \%-100 \%$. Selanjutnya, berdasarkan hasil uji koefisien regresi menunjukkan bahwa nilai signifikansinya sebesar 0,000. Karena nilai signifikansinya lebih kecil dari 0,05 dan t hitung (6.608) lebih besar dari t tabel (2.03452) maka Ho ditolak, artinya bahwa penerapan alat peraga puzzle dengan menggunakan metode demonstrasi berpengaruh signifikan terhadap motivasi belajar siswa pada pembelajaran matematika materi bangun datar di kelas IV MI An-Nur Kota Cirebon. Oleh karena itu peneliti menyarankan agar alat peraga puzzle ini kiranya perlu diterapkan dalam proses pembelajaran matematika khususnya materi bangun datar sehingga proses pembelajaran lebih aktif, menarik dan menyenangkan.

\section{Daftar Rujukan}

Agustini, Ketut. 2013. Pengaruh Penggunaan Simulasi Binary Tree Berbasis Cai Terhadap Motivasi dan Hasil Belajar Matematika Diskrit Mahasiswa Jurusan PTI Undiksha. Jurnal Pendidikan Indonesia Vol. 2, No. 1, April 2013

Akhdinirwanto, R. W. (2011). Peningkatan Motivasi Belajar Fisika Melalui Metode Demonstrasi pada Siswa SMP Negeri 5 Wates. Prosiding Seminar Nasional Penelitian, Pendidikan dan Penerapan MIPA (pp. 93-100). Yogyakarta: FMIPA Universitas Negeri Yogyakarta.

Arifuddin, A., \& Arrosyid, S. R. (2017). Pengaruh Metode Demonstrasi dengan Alat Peraga Jembatan Garis Bilangan Terhadap Hasil Belajar Matematika Materi Bilangan Bulat. Al Ibtida: Jurnal Pendidikan Guru MI, 4(2), 165-178.

Arikunto, S. (2011). Dasar-dasar Evaluasi Pendidikan. Jakarta: Bumi Aksara.

Arjanggi, Tandililing, E., \& Ramdani, D. (2013). Peningkatan Motivasi dan Hasil Belajar Siswa Melalui Penerapan Metode Demonstrasi Berbantuan Alat Peraga Bangun Ruang pada Pembelajaran Matematika. Jurnal Pendidikan dan Pembelajaran, 2(4), t.h.

Arsyad, A. (2011). Media Pembelajaran. Jakarta: PT Raja Grafindo Persada.

Astuti, N. A., Parmiti, D. P., \& Wirya, N. (2014). Penerapan Metode Bermain Puzzle Berbantuan Brain Gym untuk Meningkatkan Kemampuan Kognitif pada Anak Usia Dini. e-Journal PG-PAUD Universitas Pendidikan Ganesha, 2(1), 52-62.

Benge, K. (2017). Hubungan Antara Minat Dan Motivasi, 1, 231-238.

Elan, Muiz, D. A., \& Feranis. (2017). Penggunaan Media Puzzle untuk Meningkatkan Kemampuan Mengenal Bentuk Geometri. Jurnal PAUD Agapedia, 1(1), 66-75.

Fuadiah, N. F., Zulkardi, \& Saleh, T. (2009). Pengembangan Perangkat Pembelajaran pada Materi Geometri dan Pengukuran dengan Pendekatan Pendidikan Matematika Realistik Indonesia di SD Negeri 179 Palembang. Jurnal Pendidikan Matematika, 3(2), 73-84.

Hidayat, R. (2017). Keefektifan Model Pembelajaran Think Talk Write Berbantu Media Puzzle Terhadap Hasil Belajar Siswa Kelas V Mata Pelajaran IPS SD Negeri Kutorisari 02 Batang, 1, 179-185. Retrieved from https://ejournal.undiksha.ac.id/index.php/JISD/article/view/11839/7703

Ilmiah, J., \& Sosial, I. (2017). Kelas vii semester ii di smp negeri i gianyar Anak Agung Gede Agung Darmawan SMP Negeri I Gianyar, 3, 1-13.

Kardiyasa, I. K., Dantes, N., \& Parmiti, D. P. (2016). Determinasi Kecenderungan Tipe Belajar Visual Auditory Kinestetik ( Vak ) Terhadap Sikap Ilmiah Pada Mata Pelajaran Ipa Ditinjau Dari Jenis Kelamin Siswa Kelas V Sd Di Gugus I Kecamatan Buleleng, (1).

Kembar, I. M., Wirya, I. N., \& Parmiti, D. P. (2013). Penerapan Metode Demonstrasi Berbantuan Media Kartu Gambar Untuk Meningkatkan Kemampuan Moral Berkarakter Anak Tk Bayu Kumara Banyuseri, 1-10. 
Lestari, N. S., Raga, I. G., \& Sudatha, I. W. (2014). Ni Komang Ayu Sri Lestari1. e-Journal PG PAUD Universitas Pendidikan Ganesha, 2(1), 1-10.

Morrison, JA, dan Estes, J. (n.d.). Using Scientist andReal-World Scenario in Professional Developmentfor Middle School Science Teacher. Journalof Science TeUsing Scientist andReal-World Scenario in Professional Developmentfor Middle School Science Teacheracher Education. 18 (2): 165-184. Retrieved from https://www.jstor.org/stable/43156415?seq=1\#page_scan_tab_contents

Nyoman, N. (2013). Penerapan Metode Demonstrasi dengan Media Kartu Gambar untuk Meningkatkan Kemampuan Kognitif Anak Kelompok A di PAUD Widya Dharma Bondalem Tejakula.

Rahmadonna, S., \& Fitriyani. (2011). Penerapan Pembelajaran Kontekstual pada Mata Pelajaran Matematika untuk Meningkatkan Motivasi Belajar Siswa SMA. Majalah Ilmiah Pembelajaran, 7(1), 76-95.

Sanjaya, W. (2009). Strategi Pembelajaran Berorientasi Standar Proses Pendidikan. Jakarta: Kencana.

Sartika, R., Kaswari, \& Suryani. (2013). Penggunaan Alat Peraga Kertas Berpetak pada Pembelajaran Matematika Kelas V MIS Al Mustaqim Sungai Raya. Jurnal Pendidikan dan Pembelajaran, 2(3), t.h.

Srianis, K., Suarni, N. K., \& Ujianti, P. R. (2014). Penerapan Metode Bermain Puzzle Geometri untuk Meningkatkan Perkembangan Kognitif Anak dalam Mengenal Bentuk. e-Journal PG PAUD Universitas Pendidikan Ganesha, 2(1), 210-221.

Sudjana, N. (2014). Dasar-Dasar Proses Belajar Mengajar. Bandung: PT. Sinar Baru Algensindo.

Sugiarta, I. A., Gitakarma, M. S., \& Nugraha, I. P. (2015). Penerapan Metode Demonstrasi Berbantuan Alat Peraga Kelistrikan untuk Meningkatkan Aktivitas dan Hasil Belajar Prakarya dan Kewirausahaan Siswa Kelas X.MIA1 SMAN 2 Singaraja Tahun Ajaran 2014/201. Jurnal JPTE Universitas Pendidikan Ganesha, 4(1), 173-184.

Sugiyono. (2015). Metode Penelitian Pendidikan. Bandung: PT Alfa Beta.

Sundayana, R. (2016). Media Dan Alat Peraga Dalam Pembelajaran Matematika. Bandung: Alfabeta.

Purwanita, N. W. H., Dantes, N., \& Setuti, N. M. (2013). Motivasi Belajar Siswa Yang Mengalami Kesulitan. Jurnal Pendidikan Dan Kejuruan, 8(1), 40-50.

Tantri, N. L. (2013). Pengaruh Model Pembelajaran Quantum Teaching Bermuatan Permainan Puzzle Terhadap Hasil Belajar Ipa Kelas Iv Sd Gugus I Kecamatan Nusa Penida Universitas Pendidikan Ganesha.

Retrieved

from https://ejournal.undiksha.ac.id/index.php/JJPGSD/article/view/917/787 